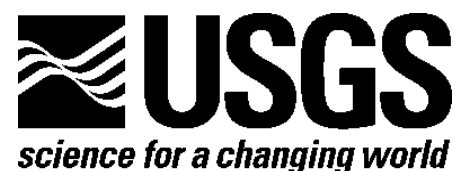

Gas, Water, and Oil Production from the Wasatch Formation, Greater Natural Buttes Field, Uinta Basin, Utah

By Philip H. Nelson and Eric L. Hoffman

Open-File Report 2009-1049

U.S. Department of the Interior

U.S. Geological Survey 


\section{U.S. Department of the Interior \\ KEN SALAZAR, Secretary}

\section{U.S. Geological Survey \\ Suzette M. Kimball, Acting Director}

U.S. Geological Survey, Reston, Virginia 2009

For product and ordering information:

World Wide Web: http://www.usgs.gov/pubprod

Telephone: 1-888-ASK-USGS

For more information on the USGS - the Federal source for science about the Earth, its natural and living resources, natural hazards, and the environment:

World Wide Web: http://www.usgs.gov

Telephone: 1-888-ASK-USGS

Suggested citation:

Nelson, P.H., and Hoffman, E.L., 2009, Gas, water, and oil production from the Wasatch Formation, Greater Natural Buttes field, Uinta Basin, Utah: U.S. Geological Survey Open-File Report 2009-1049, 19 p., 1 plate.

Any use of trade, product, or firm names is for descriptive purposes only and does not imply endorsement by the U.S. Government.

Although this report is in the public domain, permission must be secured from the individual copyright owners to reproduce any copyrighted material contained within this report. 


\section{Table of Contents}

Abstract Introduction .

\section{Figures}

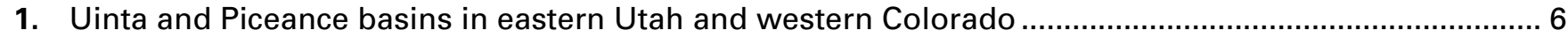

2. Wells selected for study in Greater Natural Buttes field ........................................................................ 7

3. Example plot of fluid production versus time with corresponding

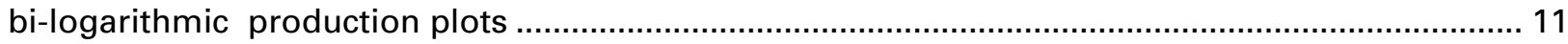

4. Example plot of fluid production versus time with vector plots of changes in production

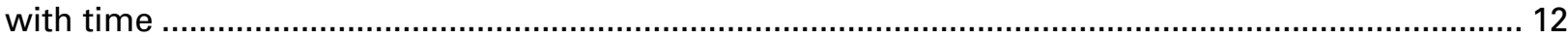

5. Increases and decreases in water and gas, keyed to well location...................................................... 15

6. Plots of gas and water production at initial time as a function of the number of sandstone

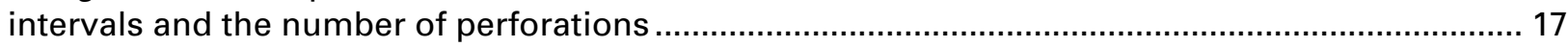

\section{Tables}

1. List of wells used in this study 9

2. Summary statistics for gas, oil, water, water:gas ratio, and oil:gas ratio 13

\section{Plate}

1. Gas, Oil, and Water Production from the Wasatch Formation, Greater Natural Buttes Field

\section{Appendix 1}

List of wells, and average daily production rates of gas, oil, and water at initial and 5-year times. Well locations from Utah Division of Oil, Gas, and Mining (2008). Appendix1.xls. 


\section{Conversion Factors}

\begin{tabular}{|c|c|c|}
\hline Multiply & By & To obtain \\
\hline \multicolumn{3}{|c|}{ Length } \\
\hline foot (ft) & 0.3048 & meter (m) \\
\hline mile (mi) & 1.609 & kilometer (km) \\
\hline \multicolumn{3}{|c|}{ Volume } \\
\hline $\begin{array}{l}\text { barrel (bbl), (petroleum, } \\
1 \text { barrel=42 gal) }\end{array}$ & 0.1590 & cubic meter $\left(\mathrm{m}^{3}\right)$ \\
\hline cubic foot $\left(\mathrm{ft}^{3}\right)$ & 0.02832 & cubic meter $\left(\mathrm{m}^{3}\right)$ \\
\hline \multicolumn{3}{|c|}{ Flow rate } \\
\hline cubic foot per day $\left(\mathrm{ft}^{3} / \mathrm{d}\right)$ & 0.02832 & cubic meter per day $\left(\mathrm{m}^{3} / \mathrm{d}\right)$ \\
\hline \multicolumn{3}{|c|}{ Pressure } \\
\hline atmosphere, standard (atm) & 101.3 & kilopascal (kPa) \\
\hline bar & 100 & kilopascal (kPa) \\
\hline pound per square inch $\left(\mathrm{lb} / \mathrm{in}^{2}\right)$ & 6.895 & kilopascal (kPa) \\
\hline \multicolumn{3}{|c|}{ Density } \\
\hline pound per cubic foot $\left(\mathrm{lb} / \mathrm{ft}^{3}\right)$ & 16.02 & $\begin{array}{l}\text { kilogram per cubic meter } \\
\left(\mathrm{kg} / \mathrm{m}^{3}\right)\end{array}$ \\
\hline pound per cubic foot $\left(\mathrm{lb} / \mathrm{ft}^{3}\right)$ & 0.01602 & $\begin{array}{l}\text { gram per cubic centimeter } \\
\left(\mathrm{g} / \mathrm{cm}^{3}\right)\end{array}$ \\
\hline
\end{tabular}




\title{
Gas, Water, and Oil Production from the Wasatch Formation, Greater Natural Buttes Field, Uinta Basin, Utah
}

\author{
By Philip H. Nelson and Eric L. Hoffman'
}

\begin{abstract}
Gas, oil, and water production data were compiled from 38 wells with production commencing during the 1980s from the Wasatch Formation in the Greater Natural Buttes field, Uinta Basin, Utah. This study is one of a series of reports examining fluid production from tight gas reservoirs, which are characterized by low permeability, low porosity, and the presence of clay minerals in pore space. The general ranges of production rates after 2 years are 100-1,000 mscf/day for gas, 0.35-3.4 barrel per day for oil, and less than 1 barrel per day for water. The water:gas ratio ranges from 0.1 to 10 barrel per million standard cubic feet, indicating that free water is produced along with water dissolved in gas in the reservoir. The oil:gas ratios are typical of a wet gas system. Neither gas nor water rates show dependence upon the number of perforations, although for low gasflow rates there is some dependence upon the number of sandstone intervals that were perforated. Over a 5-year time span, gas and water may either increase or decrease in a given well, but the changes in production rate do not exhibit any dependence upon well proximity or well location.
\end{abstract}

\section{Introduction}

Tight gas sandstones now contribute a significant fraction of gas production in the United States. Despite this success, many questions remain concerning the nature of fluids in tight (low permeability) gas systems. This study is part of an ongoing effort to examine the early production from a number of tight gas systems in the Rocky Mountain region of the United States (Nelson and others, 2008). Early production, rather than cumulative production, is examined in order to gain a record of fluid flow unperturbed by well interference and pressure reduction. By conducting a systematic study of a number of tight gas systems, we hope to gain insight into the fluid-flow characteristics of reservoirs and ultimately relate those characteristics to the geological setting and hydrocarbon-charging scenario. The purpose of this report is to document our findings for gas, water, and oil production from the Greater Natural Buttes field, which lies in the eastern portion of the Uinta Basin in Uintah County, Utah (fig. 1).

1. Metropolitan State College of Denver, Colo. 


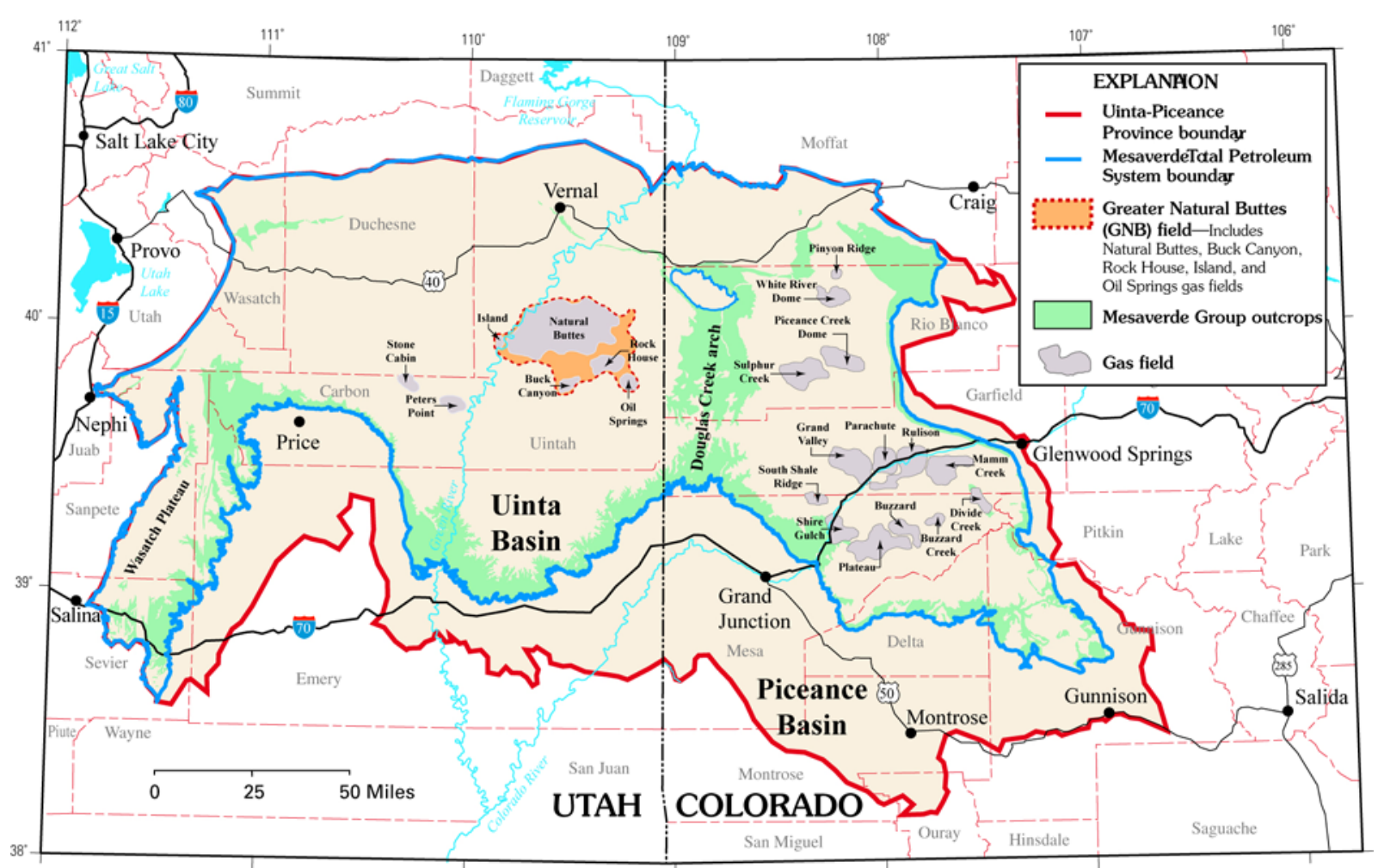

Figure 1 Uinta and Piceance basins in eastern Utah and western Colorado. Wells used in this study are located in the Natural Buttes and Island fields within the Greater Natural Buttes field. The Uinta-Province boundary and the Mesaverde Total Petroleum System boundary were defined for an oil and gas assessment of the basins. Figure from Johnson and Roberts (2003).

Wells in this study extend over six townships of the Greater Natural Buttes field (fig. 2), where gas is produced from low permeability sandstones of the Wasatch and Mesaverde Formations. In an assessment of oil and gas potential in the Uinta and Piceance basins, Greater Natural Buttes field was incorporated within the Mesaverde Total Petroleum System (Johnson and Roberts, 2003). Production examined here is from the Wasatch Formation; Mesaverde production is not included because production from the Mesaverde is generally comingled with Wasatch production. Wells in this study are located in the Natural Buttes Unit and Island Unit of the Greater Natural Buttes field. A fairway of enhanced gas production (fig. 2) accounts for most of the production from the field, when production from combined Mesaverde and Wasatch intervals are considered (Stancel and others, 2008). 


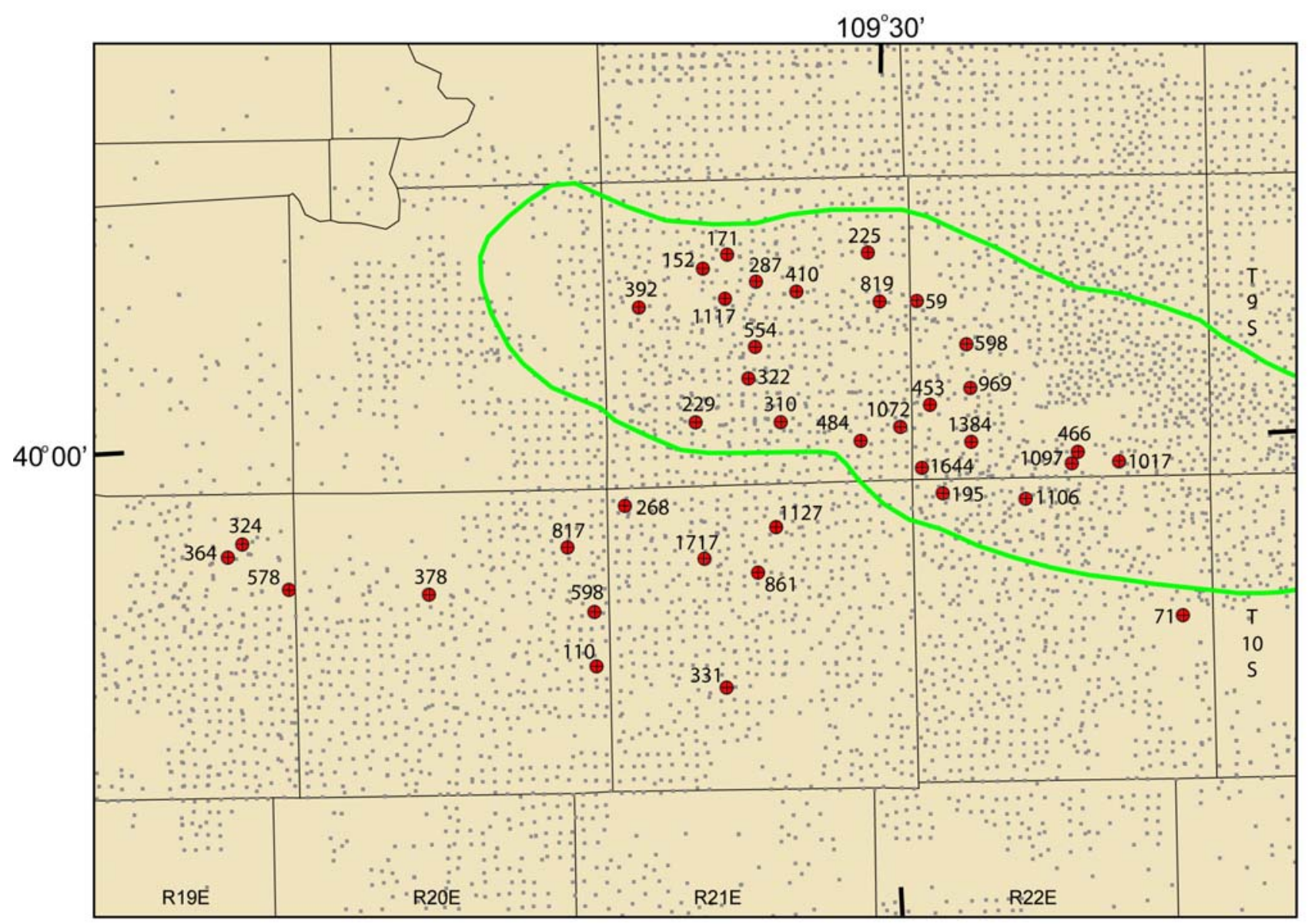

\title{
Explanation
}

\author{
$\oplus^{554}$ Wells examined in this study. Value gives \\ initial gas production rate in thousands \\ of cubic feet per day. \\ Wells not examined in this study \\ Outline of fairway of enhanced gas production
}

Figure 2. Wells selected for study in Greater Natural Buttes field. Outline of fairway (in green) after Stancel and others (2008). Method of obtaining values of initial gas rates is explained in the text. Locations of wells selected for study from Utah Division of Oil, Gas, and Mining (2008) and locations of other wells from Utah Division of Oil, Gas, and Mining (2009).

\section{Geological Setting}

The upper Paleocene to lower Eocene Wasatch Formation is described as consisting "predominantly of sandstones and variegated red, green, and gray shale deposited in a fluvial setting, and is distinguished from the underlying Tuscher Formation by the presence of varicolored shales and general lack of white, kaolinitic sandstone" (Johnson, 2003, p. 4).

Johnson (2003) provides a north-south cross section that includes three wells in the Greater Natural Buttes field and Dubiel (2003), using a previously published cross section by Johnson (1989), provides a westeast cross section that includes five wells in the Greater Natural Buttes field. These cross sections indicate a 
thickness of the Wasatch Formation of about 3,000 ft in the western part of the area, thinning to 2,000 $\mathrm{ft}$ in the east. The Flagstaff Member of the Green River Formation, a late Paleocene lacustrine unit, overlies the Mesaverde Formation and underlies the Wasatch Formation in the eastern part of the area (pl. 1, wells 18 and 19 of Dubiel, 2003). At least one well that has upper perforations in the Wasatch Formation and some deeper perforations in the Flagstaff Member has been included in the present report.

In the Greater Natural Buttes field, the Wasatch Formation is regarded as a tight reservoir (permeability less than 0.1 millidarcy (md)) for regulatory purposes (Osmond, 1992). According to Stancel and others (2008), porosity ranges from 6 to 20 percent and permeability is as high as $1 \mathrm{md}$. Based on 409 samples from the Wasatch Formation, average porosity is 8.75 percent and average permeability is 0.095 md. Petrographic examination of samples from a well in sec. 25, T. 10 S., R. 19 E. provides an understanding of the generally poor porosity and permeability (Shade and Hansen, 1992, p. 199):

"From thin sections, it was possible to identify authigenic vermiform kaolinite filling pores, thin authigenic chlorite rims on grains, in addition to chlorite within grains as an alteration product and replacing biotite flakes. ... Much of the original intergranular porosity was reduced by pressure solution and grain compaction which led to cementation by syntaxial quartz and feldspar overgrowths. Alteration of unstable grains such as feldspars and lithic fragments led to the development of grain leaching and growth of authigenic clay minerals which then filled many of the remaining pores. Carbonate, halite, and anhydrite cementation further reduced the porosity.”

Descriptions of thin sections from another well in Greater Natural Buttes field also document the pervasiveness of diagenetic clays and cements (Pitman and others, 1986).

Based on uncorrected drillstem tests, pressures are in the normal (hydrostatic) range in the Wasatch Formation, and Mesaverde reservoirs are slightly overpressured (Osmond, 1992). A pressure-depth plot by Stancel and others (2008) shows normal pressures in the Wasatch Formation at depths shallower than 6,000 ft, an increase to slight overpressures at a depth of 7,000 ft in the Wasatch Formation, and pressure-depth ratios of around $0.62 \mathrm{psi} / \mathrm{ft}$ at depths greater than 7,500 ft in the Mesaverde Formation.

Gas isotopic data and thermal maturity constraints have led Rice and others (1992) to conclude that the gas produced from the Wasatch Formation in the Greater Natural Buttes field was probably generated in coals and carbonaceous shales of the underlying Mesaverde Formation. They infer that gas migrated upwards along fractures into the Wasatch Formation. With a series of south-north cross-sections, Stancel and others (2008) show that the thickness of the gas-saturated interval and initial gas-flow rates both increase in the direction of increasing thermal maturity; the thickness of the gas-saturated interval in the Wasatch Formation and Mesaverde Formation exceeds 5,000 ft in some areas. The greater vertical extent of the gas-saturated column in areas of higher thermal maturity is consistent with the concept of vertical migration of gas.

\section{Completion Procedures}

Most wells were acidized and all were hydraulically fractured with sand and water. Excluding 4 wells in the Island Unit, our analysis of completion records (IHS Energy, 2008) for 34 wells in the Greater Natural Buttes field show median values of 3,000 gallons of acid, 75,000 gallons of water, and 150,000 pounds of sand, corresponding to median values of 2 pounds of sand per gallon of water and 5,374 gallons of water per perforation. Volumes applied to four wells in the Island Unit were greater because of the higher number of perforations (table 1), with an average value of 2,968 gallons of water per perforation.

\section{Well Selection and Data-Processing Procedures}

Only wells with production from the Wasatch Formation were used in this study, which is further limited to wells that were drilled and put into production during the years 1979-1986. Later, as the field matured, wells were drilled into the deeper Mesaverde Formation and production from the Mesaverde was comingled with the Wasatch Formation. Comingled production from the Wasatch Formation and the underlying Mesaverde Formation was examined but is not included in our tabulations and plots. Wells drilled by Belnorth (Belco) in the 
Chapita Wells Unit (T. 9 S., R. 22 E.) were completed in 1959-1961 but were not included in this study because records were not available. Records for wells drilled and completed more recently in the Chapita Wells Unit were not included in this study because the water production was accumulated and reported after a number of months, rather than every month. The four wells in the Island Unit (table 1) were originally operated by Wexpro. The other 34 wells in this study (table 1) were originally operated by the Coastal Oil and Gas Corporation or its subsidiaries, Colorado Interstate Gas Exploration and Gas Producing Enterprises, Inc.

Fluids from the 38 wells examined in this study are produced from multiple perforated intervals; the number of intervals listed in table 1 were determined by allocating the perforation depths to sandstone intervals, consulting well logs where necessary. The vertical extent of the perforated intervals, which is the depth of the bottom perforation minus the depth of the top perforation, ranges from 215 to 2,308 ft (table 1). In the four Island Unit wells that were operated by Wexpro, the number of perforations ranges from 63 to 141 and the number of sandstone intervals ranges from 3 to 21 . In the other 34 wells, the number of perforations ranges from 6 to 25 and the number of sandstone intervals ranges from 2 to 12.

Production data were obtained from the IHS Energy Production database (IHS Energy, 2008), stipulating a production start date prior to the year 2000 for wells in the Greater Natural Buttes field. These production data were supplemented with data from the Utah Division of Oil, Gas, and Mining (2008) for years prior to 1985. Ancillary data for the wells were drawn from the IHS Energy Well data base (IHS Energy, 2008).

Daily production rates were computed by dividing monthly volumes by the number of days of production in a month. The resulting values of (1) gas rate, in thousands of cubic feet per day (mcf/d); (2) water rate, in barrels per day (bbl/d); and (3) oil rate, in barrels per day (bbl/d) are plotted on a logarithmic scale as a function of time (fig. 3A). To determine a representative flow rate of gas, oil, or water from a well, a time interval was selected early in the history of a given production record for which fluid production was judged to be representative of flow. This time interval, referred to as "initial" time in this report, is generally selected to be about two years after commencement of production; such delay serves to eliminate early transients and early changes in equipment, and reduces the likelihood that fracturing fluids are included in the water tally. For the example in figure $3 A$, the production rates were averaged over the months of August-October, 1984, resulting in the values posted on the figure.

The resulting average daily rates are then posted on summary plots with bi-logarithmic scales (figs. $3 B$ and $3 C$ ), which accommodate wide ranges of production rates. With the use of bi-logarithmic axes, constant ratios of production rates lie on 45-degree lines, the ratio increasing upwards and to the left. Low water production from well CIGE 75D of $0.12 \mathrm{bbl} / \mathrm{d}$ causes the point to plot at the bottom of the graph (fig. 3B). The water:gas ratio for this well, $0.0625 \mathrm{bbl} / \mathrm{mmscf}$, which is represented as a diagonal line, is the lowest of the wells examined in this study. In similar fashion, the initial oil rate of $2.80 \mathrm{bbl} /$ day and gas rate of 1,717 mscf/day determine the location of the point in figure $3 C$, with an oil:gas ratio of $1.63 \mathrm{bbl} / \mathrm{mmscf}$ represented by a diagonal line. Wet gases, also called condensate gases, have gas:oil ratios in excess of 50,000 scf/bbl, or oil:gas ratios of less than $20 \mathrm{bbl}$ of condensate / mmscf of gas (McCain, 1990), and occupy the lower right corner of the plot. Thus, the representative data point in figure 3C lies within the wet gas field. 
Table 1 List of wells used in this study, with the top and bottom depths of perforated intervals in feet, the number of feet perforated, and the number of sandstone intervals perforated. Information from IHS Energy (2008) and Utah Division of Oil, Gas, and Mining (2008).

\begin{tabular}{|c|c|c|c|c|c|c|c|c|c|}
\hline API well number & Lease name & $\begin{array}{c}\text { Well } \\
\text { number }\end{array}$ & $\begin{array}{c}\text { Top depth } \\
\text { (ft) }\end{array}$ & $\begin{array}{c}\text { Bottom } \\
\text { depth (ft) }\end{array}$ & $\begin{array}{l}\text { No. } \\
\text { Perfs }\end{array}$ & $\begin{array}{c}\text { No. } \\
\text { Intervals }\end{array}$ & Section & Township & Range \\
\hline 43047307370000 & $\mathrm{CIGE}$ & 25 & 4892 & 6910 & 19 & 10 & 34 & $9 \mathrm{~S}$ & $22 \mathrm{E}$ \\
\hline 43047309100000 & CIGE & 370 & 5101 & 6766 & 20 & 12 & 21 & 9S & $21 \mathrm{E}$ \\
\hline 43047307400000 & $\mathrm{CIGE}$ & 40 & 5133 & 6621 & 17 & 7 & 3 & $10 \mathrm{~S}$ & $21 \mathrm{E}$ \\
\hline 43047308510000 & CIGE & $54 \mathrm{D}$ & 5052 & 5792 & 11 & 6 & 35 & 9S & $21 \mathrm{E}$ \\
\hline 43047305500000 & CIGE & 61 & 5193 & 6306 & 12 & 4 & 13 & 9S & $21 \mathrm{E}$ \\
\hline 43047309490000 & CIGE & $63 \mathrm{D}$ & 4933 & 5558 & 10 & 3 & 29 & 9S & $22 \mathrm{E}$ \\
\hline 43047309510000 & $\mathrm{CIGE}$ & $68 \mathrm{D}$ & 4848 & 7156 & 23 & 12 & 35 & 9S & $22 \mathrm{E}$ \\
\hline 43047306340000 & CIGE & 72 & 5353 & 7055 & 21 & 6 & 18 & 9S & $21 \mathrm{E}$ \\
\hline 43047309540000 & $\mathrm{CIGE}$ & $75 D$ & 5113 & 6230 & 23 & 8 & 8 & $10 \mathrm{~S}$ & $21 \mathrm{E}$ \\
\hline 43047308700000 & $\mathrm{CIGE}$ & $78 \mathrm{C}$ & 6027 & 7194 & 6 & 3 & 16 & $9 \mathrm{~S}$ & $21 \mathrm{E}$ \\
\hline 43047311510000 & CIGE & 910 & 5285 & 7231 & 11 & 5 & 15 & $9 \mathrm{~S}$ & $21 \mathrm{E}$ \\
\hline 43047308330000 & CIGE & $36 \mathrm{D}$ & 5149 & 5975 & 15 & 6 & 32 & 9S & $22 \mathrm{E}$ \\
\hline 43047304980000 & CIGE & 30 & 4975 & 5875 & 14 & 5 & 6 & $10 \mathrm{~S}$ & $21 \mathrm{E}$ \\
\hline 43047305080000 & CIGE & 34 & 5230 & 6576 & 16 & 4 & 13 & $10 \mathrm{~S}$ & $20 \mathrm{E}$ \\
\hline 43047303340000 & CIGE & 4 & 4568 & 5918 & 20 & 6 & 9 & $10 \mathrm{~S}$ & $21 \mathrm{E}$ \\
\hline 43047304920000 & CIGE & 42 & 4906 & 6441 & 20 & 11 & 25 & 9S & $21 \mathrm{E}$ \\
\hline 43047305270000 & CIGE & 44 & 5733 & 7188 & 10 & 6 & 9 & $9 \mathrm{~S}$ & $21 \mathrm{E}$ \\
\hline 43047305290000 & $\mathrm{CIGE}$ & 46 & 5173 & 7190 & 14 & 8 & 21 & 9S & $21 \mathrm{E}$ \\
\hline 43047312390000 & ISLAND UNIT & 13 & 6157 & 6377 & 63 & 3 & 12 & $10 \mathrm{~S}$ & $19 E$ \\
\hline 43047316330000 & ISLAND UNIT & 19 & 5386 & 6314 & 141 & 9 & 9 & $10 \mathrm{~s}$ & $20 E$ \\
\hline 43047317020000 & ISLAND UNIT & 25 & 5982 & 6711 & 116 & 7 & 11 & $10 \mathrm{~S}$ & $19 \mathrm{E}$ \\
\hline 43047317010000 & ISLAND UNIT & 26 & 5297 & 6907 & 141 & 21 & 2 & $10 \mathrm{~s}$ & $19 \mathrm{E}$ \\
\hline 43047305140000 & NBU & $32 Y$ & 4960 & 5868 & 13 & 4 & 20 & 9S & $22 \mathrm{E}$ \\
\hline 43047305030000 & NBU & $35 Y$ & 5067 & 6225 & 25 & 8 & 29 & 9S & $21 \mathrm{E}$ \\
\hline 43047308370000 & NBU & $53 \mathrm{~N}$ & 5438 & 7249 & 13 & 5 & 9 & 9S & $21 \mathrm{E}$ \\
\hline 43047305480000 & NBU CIGE & $59-21-10-21$ & 5410 & 5625 & 6 & 2 & 21 & $10 \mathrm{~s}$ & $21 \mathrm{E}$ \\
\hline 43047305360000 & NBU & $38 \mathrm{~N} 2$ & 5156 & 6196 & 9 & 3 & 13 & $10 \mathrm{~S}$ & $22 \mathrm{E}$ \\
\hline 43047312240000 & NBU & $41 \mathrm{~J}$ & 5163 & 6404 & 16 & 6 & 31 & 9S & $22 \mathrm{E}$ \\
\hline 43047317350000 & NBU & 42 & 5516 & 6153 & 14 & 5 & 30 & 9S & $22 \mathrm{E}$ \\
\hline 43047305380000 & NBU & $48 N 3$ & 6054 & 6948 & 11 & 4 & 18 & 9S & $22 \mathrm{E}$ \\
\hline 43047310970000 & NBU & $63 N_{3}$ & 6004 & 6528 & 12 & 6 & 12 & 9S & $21 \mathrm{E}$ \\
\hline 43047310980000 & NBU & $64 N 3$ & 6444 & 6929 & 9 & 3 & 8 & 9S & $21 \mathrm{E}$ \\
\hline 43047310880000 & NBU & $72 \mathrm{N3}$ & 5740 & 6083 & 14 & 5 & 12 & $10 \mathrm{~S}$ & $20 \mathrm{E}$ \\
\hline 43047310870000 & NBU & $74 \mathrm{N3}$ & 5244 & 5947 & 11 & 3 & 24 & $10 \mathrm{~S}$ & $20 \mathrm{E}$ \\
\hline 43047312400000 & NBU & $80 \mathrm{~V}$ & 5280 & 6794 & 20 & 8 & 34 & $9 \mathrm{~S}$ & $22 \mathrm{E}$ \\
\hline 43047312350000 & NBU & $83\rfloor$ & 5542 & 6213 & 6 & 4 & 27 & 9S & $21 \mathrm{E}$ \\
\hline 43047312450000 & NBU & $84 \mathrm{~V}$ & 5139 & 7227 & 19 & 8 & 6 & $10 \mathrm{~S}$ & $22 \mathrm{E}$ \\
\hline 43047312460000 & NBU & $85 J$ & 4691 & 5666 & 13 & 7 & 4 & $10 \mathrm{~S}$ & $22 \mathrm{E}$ \\
\hline
\end{tabular}



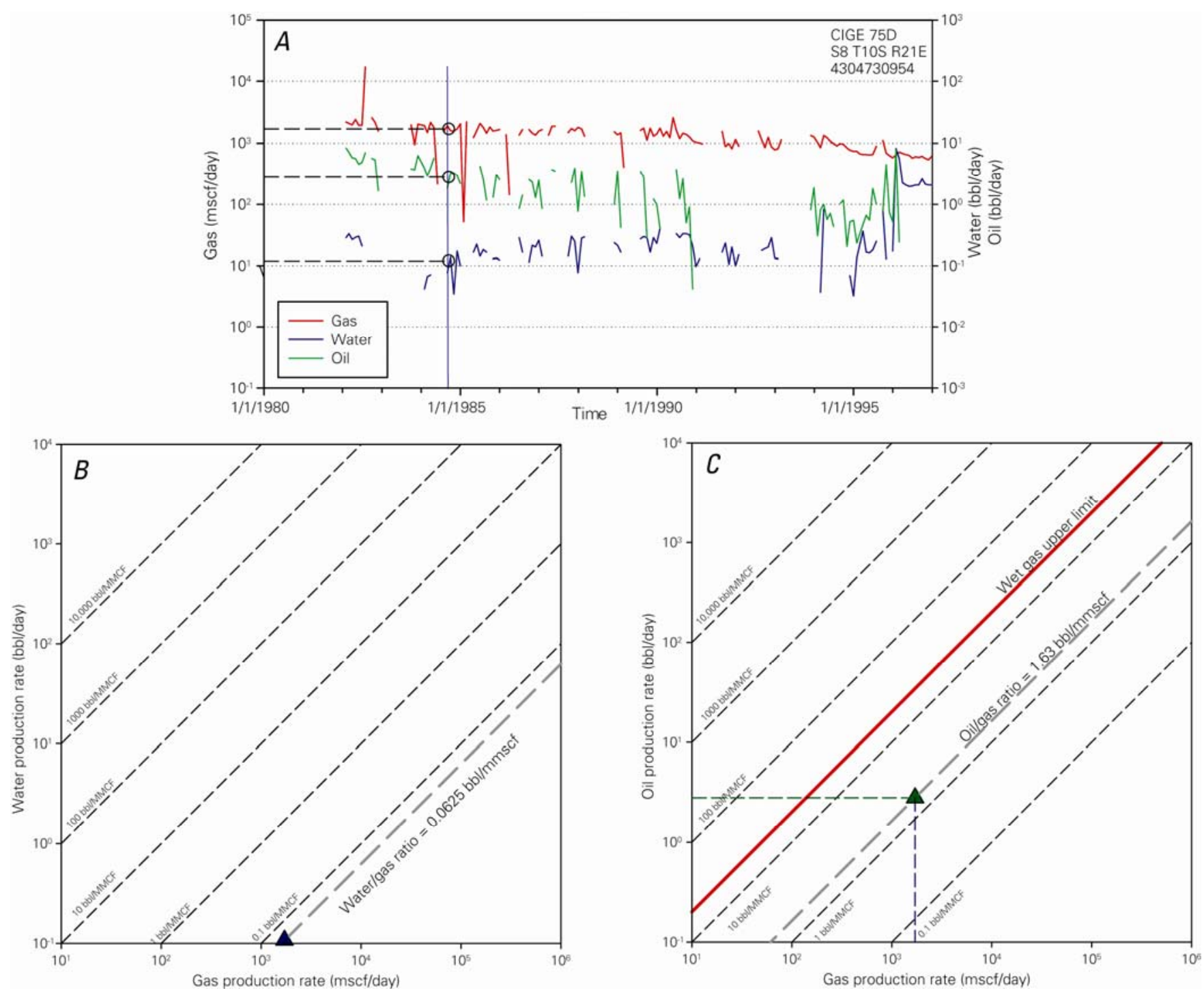

Figure 3. Example plot of fluid production versus time with corresponding bi-logarithmic production plots for the CIGE 75D well in Greater Natural Buttes field, Uinta Basin, Utah. A, Production of gas, water, and oil versus time. Vertical blue line indicates "initial" time, which is generally about two years after onset of production. Posted values are averages for months of August, September, and October, 1984. B, Water versus gas production on logarithmic axes. Triangle symbol at bottom of graph shows water and gas rate values from part $A$. The water:gas ratio of 0.0625 barrels per million standard cubic feet (bbl/mmscf) falls on a 45 -degree line. $C$, Oil versus gas production on logarithmic axes. Black triangle shows oil and gas rates from part $A$. The gas:oil (or oil:gas) ratio falls on a 45-degree line. An oil:gas ratio of $1.63 \mathrm{bbl} / \mathrm{mmscf}$ is equivalent to a gas:oil ratio of $613,420 \mathrm{scf} / \mathrm{bbl}$. [mscf/day, thousand standard cubic feet per day; scf/bbl, standard cubic feet per barrel; bbl/mmscf, barrels per million standard cubic feet]

To show the change in gas and water production in each well, a second 3-month average is computed 5 years after the initial average (fig. 4A). These "5-year" gas and water production figures are plotted on the bilogarithmic production plot (red circle in fig. 4B). Each 5-year value is linked to its initial value (black square in fig. $4 B$ ) by a dashed line, producing a vector that shows the amounts and the change of water and gas production over time. A vector of a given length and angle represents the same fractional changes in daily gas and water production regardless of where it is positioned on the graph. In the example shown in figure 4, gas production decreases slightly with time, water production increases with time, and the water:gas ratio increases with time the water:gas ratio has increased from $0.0625 \mathrm{bbl} / \mathrm{mmscf}$ in the initial sample (fig. $3 B$ ) to $0.203 \mathrm{bbl} / \mathrm{mmscf}$ in the 5-year sample (fig. 4B). 

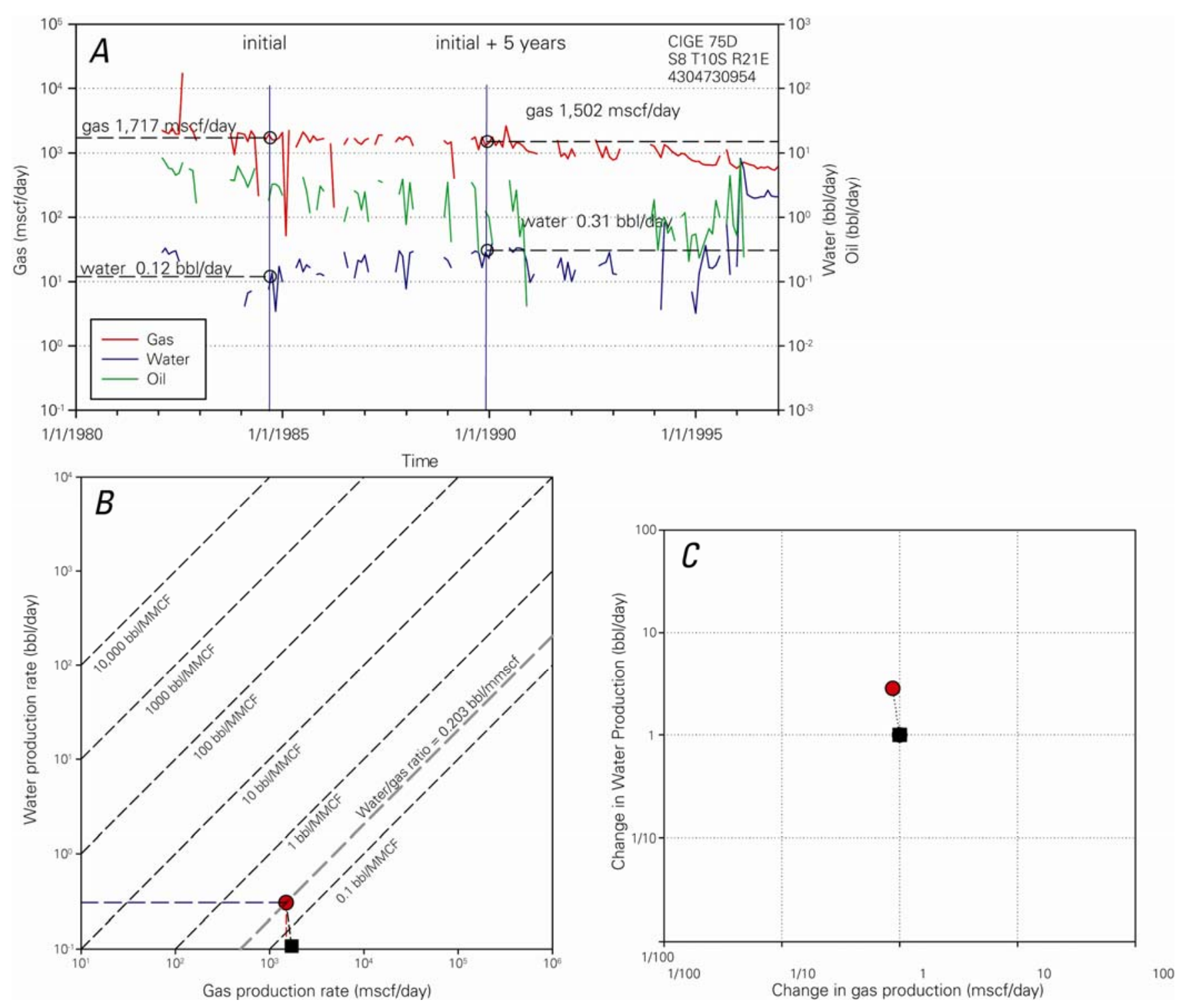

Figure 4. Example plot of fluid production versus time with vector plots of changes in production with time, for the CIGE 75D well in Greater Natural Buttes field, Uinta Basin, Utah. A, Production of gas, water, and oil versus time. B, Vector plot, with water versus gas production on logarithmic axes. The square designates the gas and water production at initial time and the circle shows production at initial plus 5-year time, thus marking the head and tail of a vector. $C$, Normalized vector plot, with change in water production versus change in gas production on logarithmic axes. The initial-time values are placed at center of plot, so all vectors for a field share a common origin. [mscf/day, thousand standard cubic feet per day; scf/bbl, standard cubic feet per barrel; bbl/mmscf, barrel per million standard cubic feet]

To clarify the relative changes in water and gas production among wells, a bi-logarithmic plot of the change in water and gas production places all early-time production at a common origin (single square at 1,1 in fig. $4 C$ ) so that changes in production over a 5-year span can be compared among wells. The length and orientation of each vector is the same in figures $4 B$ and $4 C$, but the origin, which is its value at initial time, has been translated to the center $(1,1)$ position of the plot in figure $4 C$. In this example, gas, water, and oil records were complete at the 5-year interval, but in a few cases where data were missing, values from an earlier time (three or four years after the initial time) were extrapolated to 5 years. 


\section{Discussion}

Bi-logarithmic plots summarizing the production data are shown on plate 1, along with a map of well locations and plots of fluid production as a function of time for 10 of the 38 wells that were analyzed. Production was interrupted on an annual basis for much of the roughly 25-year time spans shown in the production as a function of time plots. However, there is no indication that cessation of production impacted the flow rates in succeeding intervals.

Also shown on the production versus time plots are the time intervals selected for initial and "5-year" samples of production, denoted by two vertical lines spaced 5 years apart, as previously explained in figures 3 and 4. Some plots exhibit a high gas rate that declines rapidly during the first 2 years of production - most notably, the Island Unit 25, Island Unit 19, CIGE 46, and Natural Buttes Unit 38N2 wells (pl. 1, figs. 1-6, 1-7, $1-10$, and 1-15) - a high rate that is not sampled by the "initial" sample after 2 years of production. From these plots of production versus time, it can be seen that initial gas rates are generally in the range of 100 to 1,000 $\mathrm{mscf} / \mathrm{d}$ and initial water rates are generally less than $1 \mathrm{bbl} / \mathrm{d}$; these values are summarized in the bi-logarithmic water versus gas plot (fig. 1-2 of pl. 1). A statistical summary of fluids and fluid ratios at initial times is given in table 2.

Water:gas ratios range from 0.1 to $10 \mathrm{bbl} / \mathrm{mmscf}$ with most values ranging between 0.3 and $3 \mathrm{bbl} / \mathrm{mmscf}$, as is evidenced by the position of the data with respect to the diagonal lines in plate 1, figure 1-2. For comparison, Osmond (1992, p. 158) reports an estimate of the water:gas ratio of $3.3 \mathrm{bbl}$ of water per mmcf gas for the field. As some water can exist as a dissolved phase in gas in the reservoir, the question arises as to how much of the produced water was originally dissolved in the reservoir and then condensed at the surface. The amount of water dissolved in gas in reservoirs increases with increasing temperature and decreases with increasing pressure (McCain, 1990, p. 461). The amount released depends upon the pressure and temperature at the surface. Our computations, based upon the approach given by McCain (1990, p. 460-463) and using subsurface temperature and pressure gradients from Osmond (1992), indicate that the amount of water likely to be dissolved in reservoir gas and subsequently produced at the surface ranges from 0.3 to $0.8 \mathrm{bbl} / \mathrm{mmscf}$. Thus, some but not all, of the water produced at surface must originate as water dissolved in reservoir gas.

Table 2. Statistics for gas, oil, water, water:gas ratio, and oil:gas ratio at the initial time interval for the 38 wells listed in table 1.

\begin{tabular}{|c|c|c|c|c|c|}
\hline Statistic & $\begin{array}{c}\text { Oil } \\
\text { (bbl/day) }\end{array}$ & $\begin{array}{c}\text { Gas } \\
\text { (mscf/day) }\end{array}$ & $\begin{array}{c}\text { Water } \\
\text { (bbl/day) }\end{array}$ & $\begin{array}{c}\text { Water/gas } \\
\text { ratio } \\
\text { (bbl/mmscf) }\end{array}$ & $\begin{array}{c}\text { Oil/gas } \\
\text { ratio } \\
\text { (bbl/mmscf) }\end{array}$ \\
\hline Minimum & 0.36 & 58.6 & 0.11 & 0.06 & 0.73 \\
\hline Maximum & 10.52 & 1717.5 & 2.88 & 11.83 & 32.39 \\
\hline Average & 1.81 & 607.4 & 0.54 & 1.84 & 3.18 \\
\hline Median & 1.36 & 459.6 & 0.41 & 0.93 & 1.70 \\
\hline Count & 27 & 38 & 38 & 38 & 27 \\
\hline
\end{tabular}

Oil rates range from 0.35 to $3.5 \mathrm{bbl} / \mathrm{d}$ with one well producing at a rate of $10.5 \mathrm{bbl} / \mathrm{d}$ (pl. 1, fig. $1-3)$. Oil was reported in 27 of the 38 wells analyzed, leading to fewer data points in figure 1-3 than in figure 1-2, and the range of gas rate values is reduced as a consequence of fewer points. The oil:gas ratio ranges from roughly 1 to 5 $\mathrm{bbl} / \mathrm{mmscf}$, which is well within the wet gas field of figure $1-3$, with the exception of one value of $30 \mathrm{bbl} / \mathrm{mmscf}$ that exceeds the wet gas limit. For comparison, Osmond (1992, p. 158) reports an oil:gas ratio for the field of 7.35 bbl condensate per mmscf gas.

Incorporating the 5-year points creates the vector plot of figure 1-4 of plate 1. Comparison with figure 1-2 shows that the 5-year data lie within much the same area as the initial points, with some of the water rate values indicating lower water rates after 5 years time. However, the tight clustering of data on this plot makes it difficult to draw further conclusions about trends. 
Five-year trends are better displayed on figure 1-5 of plate 1 , where all vectors start at the 1,1 point in the center of the plot. The scattered displacements of the 5-year points from the 1,1 point illustrates the variability in declines and increases in gas and water over a 5-year time span. For points to the left of 1,1 gas production declines slowly with time, typically by less than one-third over a period of 5 years. In about half of the wells, both water and gas decline, placing the 5-year points below and to the left of the 1,1 point. In this cluster, one 5year water value is less than one-tenth of its initial value; all other water values exhibit declines that are less than one-tenth and many are less than one-third. In eight wells, gas decreases and water increases over the 5-year time span resulting in points above and to the left of the 1,1 point, and in six wells, gas and water both increase, although the increases are not great. The number of wells exhibiting an increase in water rate is about the same as the number with a decrease, although the magnitudes of the decreases are greater than the magnitudes of the increases. The plot of production versus time for well CIGE 46, in which both gas and water increase, is shown on plate 1.

The normalized vector plot is repeated in figure 5 and combined with a map to examine the possibility of spatial control on the changes in gas and water production rates over a 5-year time span. The change vectors for 38 wells are divided into five groups (color symbols in fig. 5A) according to relative increase or decrease in gas and water rates. The well symbol on the map (fig. 5B) shows the well locations of the five groups. Inspection of the well symbols shows that members of each group are scattered within the study area and show little spatial coherence. It does appear that the centroid of wells showing water increases (red and blue dots) lies west of the centroid of wells showing water decreases (orange and yellow dots), however, the separation is impaired by the mingling of the symbols. Given the lack of correlation between rate decline and well location (fig. 5), the spatial controls on variability of gas and water decline must be at a scale smaller than that of the gas field. 

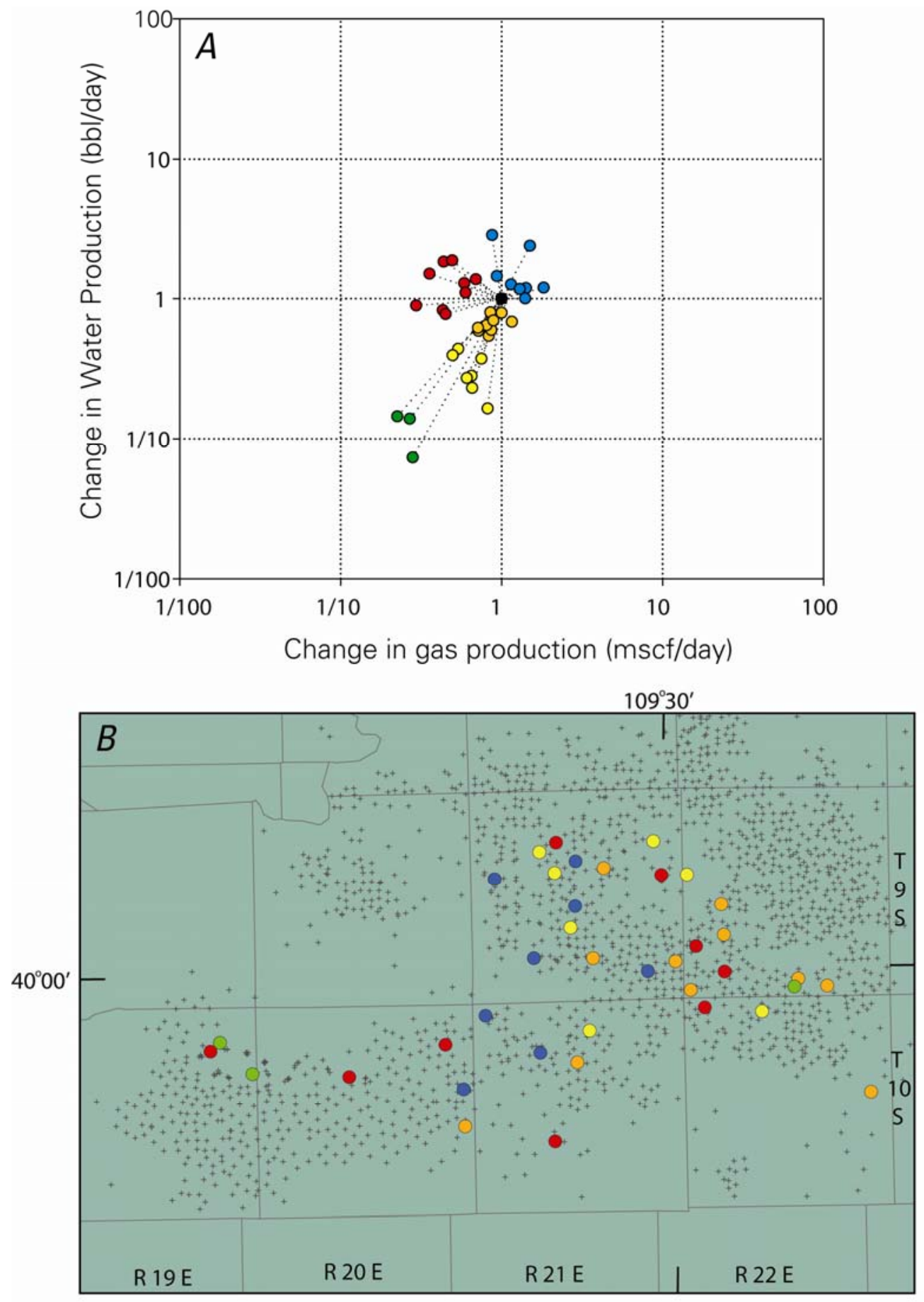

Figure 5. Increases and decreases in water and gas, keyed to well location. A, Normalized vector plot, with 5 groups of water and gas rates, separated by magnitude and angle, each group assigned a color. $B$, Map showing location of change in water and gas production rate, according to color code of part $A$. 
Variability in fluid production might also be a function of completion practices that vary among operators and are altered as new ideas and technology are introduced in a given field. This study has focused on production brought online during the 1980s by two operators in the Greater Natural Buttes field, thereby restricting some of the changes in practices (see preceding section on Completion Practices). However, multistage completions used in this and other tight gas accumulations could introduce variability in fluid production because the fluid volumes recorded at the surface represent the combined inflow from a number of sandstone intervals. The number of sandstone intervals and the number of perforations vary from well to well (table 1); a test of the relationship between these two parameters and gas and water production is shown in figure 6 . These graphs show that there is little or no relationship between gas or water production and either the number of perforations or the number of sandstone intervals. One possible exception can be seen on the plot of gas versus sandstone intervals (fig. 6A), in which a dashed line bounding the lower edge of the gas points shows an increase with the number of sandstone intervals. This suggests that production from the subset of wells with low gas production is dependent upon the number of sandstone intervals. 

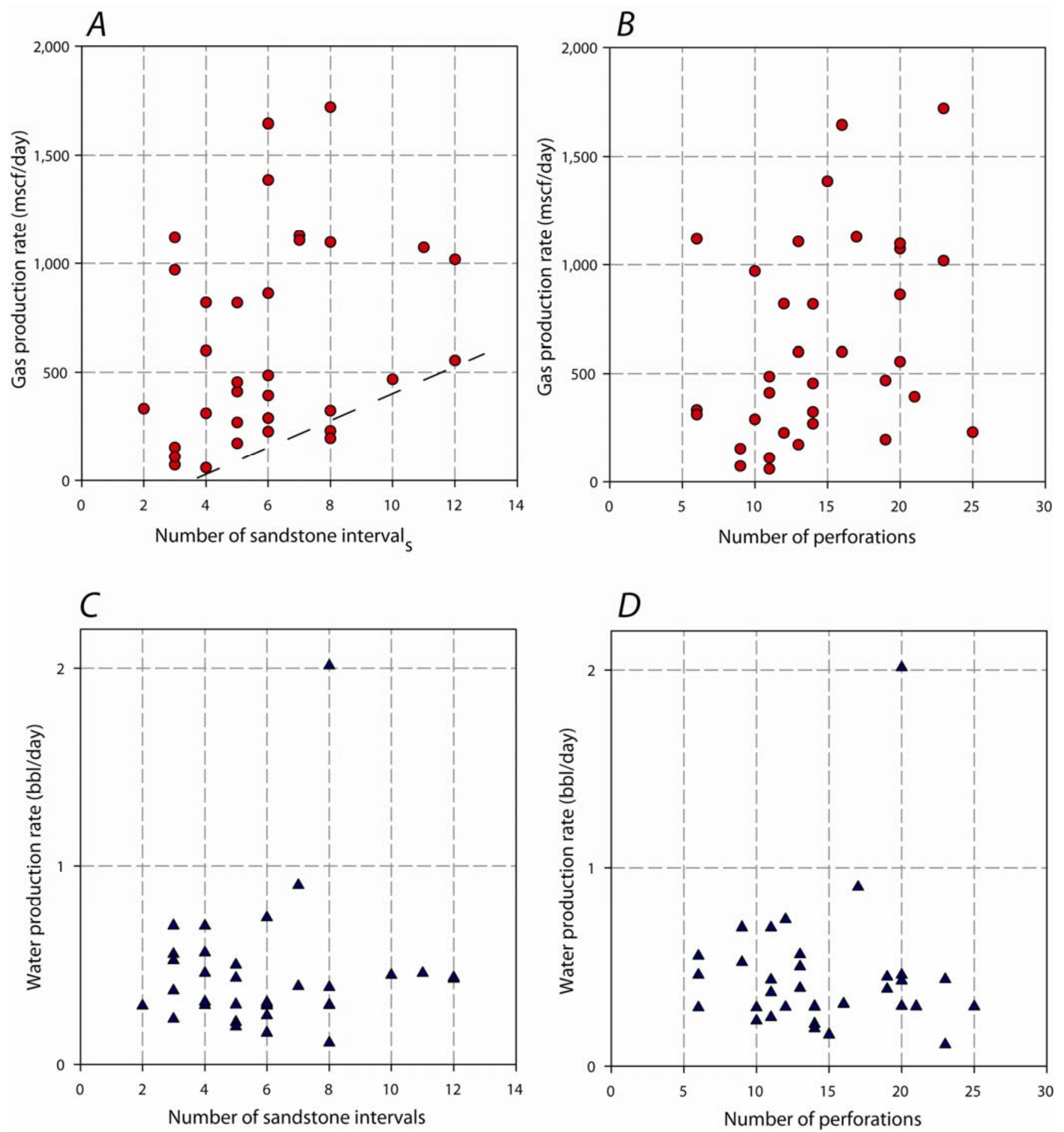

Figure 6. Plots of gas $(A, B)$ and water production $(C, D)$ at initial time (appendix 1 ) as a function of the number of sandstone intervals $(A, C)$ and the number of perforations $(B, D)$ in a well (table 1), for 34 wells in Greater Natural Buttes Field. Four wells from the Island Unit are not included on these plots. 


\section{Summary}

We have examined the gas, water, and oil production from 38 wells in the Greater Natural Buttes field that were put into production during the 1980s and have found that:

- Oil:gas ratios of 1 to $5 \mathrm{bbl} / \mathrm{mmscf}$ fall within the wet gas field, indicating that produced petroleum liquids exist in a gaseous phase in the reservoir.

- Initial gas rates, defined herein as the rates after about 2 years of production, are generally in the range of 100 to $1,000 \mathrm{mscf} /$ day and initial water rates are generally less than $1 \mathrm{bbl} / \mathrm{day}$.

- Water:gas ratios range from 0.1 to $10 \mathrm{bbl} / \mathrm{mmscf}$, indicating that much, but not all of the produced water was dissolved in gas in the reservoir.

- Neither gas nor water production rates show any dependence upon the number of perforations or the number of sandstone intervals opened to flow, with the possible exception of wells with the lowest gas flow rates, for which gas rate does increase with the number of sandstone intervals.

- Over a 5-year time period, increases and decreases in both gas and water are observed. Wells with similar increases or decreases are not located in proximity, that is, there appears to be no relation between well location and the trends of water and gas production, and therefore the well-to-well variations in changes in production must be due to causes that are connected to the spatial scale of the hydraulically induced fracture system.

\section{Acknowledgments}

Reviews by Tim Klett and Kristal Pearson of the U.S. Geological Survey led to improvements in the manuscript. Conversations with Ken Robb of Anadarko Petroleum, Jerry Cuzella of Enduring Resources, John Osmond, consultant, and Craig Morgan of the Utah Geological Survey helped improve our understanding of field history.

\section{References Cited}

Dubiel, R.F., 2003, Geology, depositional models, and oil and gas assessment of the Green River Total Petroleum System, Uinta-Piceance Province, eastern Utah, and western Colorado, chap. 5 in USGS Uinta-Piceance assessment team, compilers, Petroleum systems and geologic assessment of oil and gas in the Uinta-Piceance Province, Utah and Colorado; U.S. Geological Survey Digital Data Series 69-B, 6 p.

IHS Energy, 2008, U.S. Production and Well Data: Englewood, Colo., database available from IHS Energy, 15 Inverness Way East, D205, Englewood, CO 80112, U.S.A.

Johnson, R.C., 1989, Detailed cross sections correlating upper Cretaceous and lower Tertiary rocks between the Uinta Basin of eastern Utah and western Colorado and the Piceance Basin of western Colorado: U.S. Geological Survey Miscellaneous Investigations Series Map I-1974, 2 sheets.

Johnson, R.C., 2003, Northwest to southeast cross section of Cretaceous and lower Tertiary rocks across the eastern part of the Uinta Basin, Utah, chap. 11 in USGS Uinta-Piceance assessment team, compilers, Petroleum systems and geologic assessment of oil and gas in the Uinta-Piceance Province, Utah and Colorado, U.S. Geological Survey Digital Data Series 69-B, 6 p.

Johnson, R.C., and Roberts, S.B., 2003, The Mesaverde Total Petroleum System, Uinta-Piceance Province, Utah and Colorado, chap. 7 in USGS Uinta-Piceance assessment team, compilers, Petroleum systems and geologic assessment of oil and gas in the Uinta-Piceance Province, Utah and Colorado: U.S. Geological Survey Digital Data Series 69-B, 68 p. 
McCain, W.D., Jr., 1990, The properties of petroleum fluids: Tulsa, Okla., Pennwell Books, 548 p.

Nelson, P.H., Trainor, P.K., and Finn, T.M., in press, Gas, oil, and water production in the Wind River Basin, Wyoming: U.S. Geological Survey Scientific Investigation Report 2008-5225.

Osmond, J.C., 1992, Greater Natural Buttes gas field, Uintah County, Utah, in Fouch, T.D., Nuccio, V.F., and Chidsey, T.C., Jr., eds., Hydrocarbon and Mineral resources of the Uinta Basin, Utah and Colorado, Utah Geological Association Guidebook 20, p. 143-163.

Pitman, J.K., Anders, D.E., Fouch, T.D., and Nichols, D.J., 1986, Hydrocarbon potential of nonmarine Upper Cretaceous and Lower Tertiary rocks, eastern Uinta basin, Utah, in Spencer, C.W., and Mast, R.F., eds., Geology of tight gas reservoirs: American Association of Petroleum Geologists Studies in Geology 24, p. 235252.

Rice, D.D., Fouch, T.D., and Johnson, R.C., 1992, Influence of source rock type, thermal maturity, and migration on composition and distribution of natural gases, Uinta Basin, Utah, in Fouch, T.D., Nuccio, V.F., and Chidsey, T.C., Jr., eds., Hydrocarbon and Mineral resources of the Uinta Basin, Utah and Colorado: Utah Geological Association Guidebook 20, p. 95-121.

Shade, M.E., and Hansen, D.K.T., 1992, Drilled sidewall cores aid in interpretation of the Tertiary Wasatch Formation, Natural Buttes Field, Utah, in Fouch, T.D., Nuccio, V.F., and Chidsey, T.C., Jr., eds., Hydrocarbon and Mineral Resources of the Uinta Basin: Utah Geological Association Guidebook 20, p. 193-218.

Stancel, S.G., Cuzella, J.J., MacMillan, L., and Ragas, A., 2008, Controls on gas production along the southern flank of Greater Natural Buttes Field-A case study of the Love Area, Uinta Basin, Utah, in Longman, M.W., and Morgan, C.D., eds., Hydrocarbon systems and production in the Uinta Basin, Utah: Rocky Mountain Association of Geologists and Utah Geological Association Publication 37, p. 237-265.

Utah Division of Oil, Gas, and Mining, 2008, accessed October-November, 2008 at http://oilgas.ogm.utah.gov/.

Utah Division of Oil, Gas, and Mining, 2009, accessed January, 2009 at http://gis.utah.gov/sgid-vectordownload/utah-sgid-vector-gis-data-layers-by-category\#Energy.

\section{Appendix 1}

List of wells, and average daily production rates of gas, oil, and water at initial and 5-year times. Well locations from Utah Division of Oil, Gas, and Mining (2008). Appendix1.xls. 